Check for updates

Cite this: RSC Adv., 2018, 8, 3858

Received 31st August 2017

Accepted 22nd December 2017

DOI: $10.1039 / c 7 r a 09680 a$

rsc.li/rsc-advances

\section{Synthesis of $\mathrm{CrO}_{x} / \mathrm{C}$ catalysts for low temperature $\mathrm{NH}_{3}$-SCR with enhanced regeneration ability in the presence of $\mathrm{SO}_{2} \dagger$}

\author{
Shuohan $\mathrm{Yu}^{\mathrm{ab}}$ Sheng $\mathrm{Xu},{ }^{\mathrm{c}}$ Bowen Sun, ${ }^{\mathrm{ab}}$ Yiyang Lu, ${ }^{\mathrm{ab}}$ Lulu Li, $^{\mathrm{ab}}$ Weixin Zou, ${ }^{\mathrm{ab}}$ \\ Peng Wang, ${ }^{c}$ Fei Gao, (D) *ab Changjin Tang ${ }^{\mathrm{ab}}$ and Lin Dong (D)*ab
}

\begin{abstract}
Chromium oxide nano-particles with an average diameter of $3 \mathrm{~nm}$ covered by amorphous carbon $\left(\mathrm{CrO}_{x} / \mathrm{C}\right)$ were successfully synthesized. The synthesized $\mathrm{CrO}_{x} / \mathrm{C}$ materials were used for the selective catalytic reduction of $\mathrm{NO}_{x}$ by $\mathrm{NH}_{3}\left(\mathrm{NH}_{3}-\mathrm{SCR}\right)$, which shows superb $\mathrm{NH}_{3}-\mathrm{SCR}$ activity and in particular, satisfactory regeneration ability in the presence of $\mathrm{SO}_{2}$ compared with $\mathrm{Mn}$-based catalysts. The as-prepared catalysts were characterized by XRD, HRTEM, Raman, FTIR, BET, TPD, TPR, XPS and in situ FTIR techniques. The results indicated presence of certain amounts of unstable lattice oxygen exposed on the surface of $\mathrm{CrO}_{x}$ nano-particles with an average size of $3 \mathrm{~nm}$ in the $\mathrm{CrO}_{x} / \mathrm{C}$ samples, which led to $\mathrm{NO}$ being conveniently oxidized to $\mathrm{NO}_{2}$. The formed $\mathrm{NO}_{2}$ participated in $\mathrm{NH}_{3}-\mathrm{SCR}$ activity, reacting with catalysts via a "fast $\mathrm{NH}_{3}$-SCR" pathway, which enhanced th $\mathrm{NH}_{3}$-SCR performance of the $\mathrm{CrO}_{x} / \mathrm{C}$ catalysts. Furthermore, the stable lattice of the $\mathrm{CrO}_{x}$ species made the catalyst immune to the sulfation process, which was inferred to be the cause of its superior regeneration ability in the presence of $\mathrm{SO}_{2}$. This study provides a simple way to synthesize stable $\mathrm{CrO}_{x}$ nano-particles with active oxygen, and sheds light on designing $\mathrm{NH}_{3}-\mathrm{SCR}$ catalysts with highly efficient low temperature activity, $\mathrm{SO}_{2}$ tolerance, and regeneration ability.
\end{abstract}

\section{Introduction}

Low-temperature $\mathrm{NH}_{3}$-SCR $\left(<200{ }^{\circ} \mathrm{C}\right)$, which can be located downstream of electrostatic precipitators and even desulfurizers, where most of $\mathrm{SO}_{2}$ and dust have been removed, has been paid increasing attention in the past few decades..$^{1-4}$ Various transition metal oxides exhibit satisfactory activity for lowtemperature $\mathrm{NH}_{3}$-SCR, such as $\mathrm{Mn}, \mathrm{Fe}, \mathrm{Cu}$, and Co. ${ }^{2,5-9}$ Among them, Mn-based catalysts have become a focus for their excellent low-temperature activity and inherent environmentfriendly nature., ${ }^{\mathbf{4 1 0 - 1 2}}$ According to literature, Mn-based catalysts have a unique advantage for low-temperature SCR $\left(<200{ }^{\circ} \mathrm{C}\right)$ in contrast with other competitors. For example,

${ }^{a}$ Key Laboratory of Mesoscopic Chemistry of MOE, School of Chemistry and Chemical Engineering, Nanjing University, Nanjing 210093, PR China. E-mail: donglin@nju. edu.cn; gaofei@nju.edu.cn

${ }^{b}$ Jiangsu Key Laboratory of Vehicle Emissions Control, Center of Modern Analysis, Nanjing University, Nanjing 210093, PR China

'National Laboratory of Solid State Microstructures, College of Engineering and Applied Sciences, Collaborative Innovation Center of Advanced Microstructures, Nanjing University, Nanjing 210093, China

$\dagger$ Electronic supplementary information (ESI) available: Band energy calculation, thermochemical data, band energy data, mass of metal sulfate formed on catalysts, surface atomic concentration of $\mathrm{SO}_{2}$ poisoned $\mathrm{CrO}_{x} / \mathrm{C}-450$ sample, extra $\mathrm{NH}_{3}$-SCR and water tolerance tests, XRD patterns, FTIR data, Raman data, extra TEM image, $\mathrm{NH}_{3}$-TPD data, $\mathrm{H}_{2}$-TPR data, $\mathrm{O}_{2}$-TPD data, extra XPS spectra. See DOI: $10.1039 / \mathrm{c} 7 \mathrm{ra} 09680 \mathrm{a}$
$\mathrm{Hu}$ et al. reported a $\mathrm{Co}-\mathrm{Mn} / \mathrm{TiO}_{2}$ catalyst with superior $\mathrm{NH}_{3}-\mathrm{SCR}$ activity at $200{ }^{\circ} \mathrm{C}^{\mathbf{1 1}} \mathrm{Mn}-\mathrm{Ce}-\mathrm{Ti}$ mix-oxide catalysts were recorded to exhibit an operating temperature window from $150{ }^{\circ} \mathrm{C}$ to $200{ }^{\circ} \mathrm{C} .{ }^{12} \mathrm{We}$ also reported $\mathrm{Mn}-\mathrm{Fe}-\mathrm{Ti}$ mix-oxide catalysts with satisfactory $\mathrm{NH}_{3}$-SCR activity from $100{ }^{\circ} \mathrm{C}$ to $350{ }^{\circ} \mathrm{C} .{ }^{5}$ However, the poor $\mathrm{SO}_{2}$ resistance performance of $\mathrm{Mn}$-based catalysts limits their practical application.

According to the previous reports, ${ }^{\mathbf{4 , 1 3 - 1 5}}$ the tolerance of metal oxide based catalysts to $\mathrm{SO}_{2}$ depends on the type and oxidation state of the deposited metal, the nature of the support, and the type of reducing agent. In general, the rapid deactivation of $\mathrm{NH}_{3}$ SCR catalysts involves two main mechanisms. One is the formation of ammonium salts..$^{14,16-22}$ The $\mathrm{SO}_{2}$ in the feed gas can be oxidized to $\mathrm{SO}_{3}$ on the surface of the catalysts, and the formed $\mathrm{SO}_{3}$ would respond to $\mathrm{NH}_{3}$ and water in feed gas transforming to $\mathrm{NH}_{4} \mathrm{HSO}_{4}$. The formed $\mathrm{NH}_{4} \mathrm{HSO}_{4}$ would deposit on the surface of the catalysts, cover active sites, block pores of the catalysts, and result in the deactivation of the catalysts. The other fact is the irreversible sulfation of the active phase. ${ }^{\mathbf{1 4 , 1 6 , 1 8 - 2 3}}$ For most transition metal oxides usually reported as $\mathrm{NH}_{3}$-SCR catalysts, such as $\mathrm{Mn}, \mathrm{Fe}, \mathrm{Cu}$, and $\mathrm{Co}$, all sulfating processes are spontaneous according to their Gibbs free energy values (Table S1 $\dagger$ ). In the sulfation process, formation of a metal sulfate requires breaking the metal oxide lattice. It is reasonable to predict that the more stable the metal oxides, the more difficult it is to break the metal oxide lattice and thus, harder is the sulfation of metal oxide. In general, the metal oxide with a high melting point has 
a stable crystal lattice. Thus, the melting point can be an indicator of the stability of the crystal lattice of metal oxides. ${ }^{24}$ In the case of Mn-based catalysts, $\mathrm{MnO}_{2}$ has a low melting point (Table S1†), indicating its unstable structure, which is the cause of the severe irreversible sulfation of $\mathrm{MnO}_{2}$ in the $\mathrm{NH}_{3}$-SCR process, particularly in the low temperature range $\left(<200{ }^{\circ} \mathrm{C}\right) .^{\mathbf{1 3 , 1 4 , 2 5 - 2 8}} \mathrm{Cr}_{2} \mathrm{O}_{3}$, which has the highest melting point among the transition metal oxides with $\mathrm{NH}_{3}$-SCR activity (listed in Table $\mathrm{S} 1 \dagger$ ), was expected to have resistance to the sulfation process. Although the low $\mathrm{NH}_{3}$-SCR activity of crystalline $\mathrm{Cr}_{2} \mathrm{O}_{3}$ is unsatisfactory, amorphous $\mathrm{Cr}_{2} \mathrm{O}_{3}$ exhibits superb low temperature $\mathrm{NH}_{3}$-SCR activity, according to literature. ${ }^{29-33}$ Thus, it appears to be a promising strategy to design a SCR catalyst with both low temperature activity and $\mathrm{SO}_{2}$ tolerance via enhancing the catalytic activity of crystalline $\mathrm{Cr}_{2} \mathrm{O}_{3}$.

Compared with traditional metal oxide catalysts with a large particle size, nano-sized catalysts often have significant amounts of unsaturated-coordinated atoms exposed on their surfaces. Unsaturated-coordinated atoms are usually active; thus, nano-sized catalysts exhibit unique redox ability and enhanced catalytic activity. ${ }^{34-36}$ Therefore, decreasing the size of catalysts appears to be a promising strategy to enhance low temperature $\mathrm{NH}_{3}-\mathrm{SCR}$ performance of crystalline $\mathrm{Cr}_{2} \mathrm{O}_{3}$. However, nano-particle materials have the disadvantage of instability and tend to aggregate due to their high surface energy and their abundant surface unsaturated atoms. Recently, metal oxide nano-particles catalysts derived from MOFs material were reported. ${ }^{37-39}$ Through a thermal decomposition process under controlled atmosphere, MOFs built from metal ions or nodes and polyfunctional organic ligands can transform into nano-materials, including nano-particles, single atoms, and metal oxide clusters. Wu et al. ${ }^{\mathbf{4 0}}$ synthesized Co nano-particles and single atoms from Co MOF and Co/Zn bimetallic MOF. Similar results were also reported by $\mathrm{Li}$ et $a .^{37}$ and Sun's group. ${ }^{41}$ The carbon from the organic ligands of MOFs remains in materials and can protect metal oxide nano-particles from aggregation.

Herein, novel $\mathrm{CrO}_{x}$ nano-particles covered by amorphous carbon $\left(\mathrm{CrO}_{x} / \mathrm{C}\right)$ have been synthesized by a MOFs assisted process for low temperature $\mathrm{NH}_{3}$-SCR. MIL-101, with a metal node of $3 \mathrm{Cr}$ atoms, ${ }^{\mathbf{4 2 , 4 3}}$ was employed as a precursor. The results of the catalytic tests for $\mathrm{NH}_{3}$-SCR showed that the prepared $\mathrm{CrO}_{x}$ catalyst exhibited satisfactory activity and superior regeneration ability. According to a series of characterizations, the $\mathrm{CrO}_{x} / \mathrm{C}$ catalyst was observed to be composed of $\mathrm{CrO}_{x}$ nano-particles with an eskolaite phase and activated lattice oxygen. It was deduced that the activated lattice oxygen was closely related to the enhanced $\mathrm{NH}_{3}$-SCR activity of the $\mathrm{CrO}_{x} / \mathrm{C}$ catalyst. The stable lattice of the eskolaite phase- $\mathrm{CrO}_{x}$ inhibited the sulfating process, thus causing the $\mathrm{SO}_{2}$ tolerance and regeneration ability. To the best of our knowledge, it is the first time that a non-Mn catalyst with excellent low temperature $\mathrm{NH}_{3}$-SCR activity and remarkable regeneration ability has been reported. This study provides a simple route to synthesize stable $\mathrm{CrO}_{x}$ nano-particles with active oxygen and shed light on designing low temperature $\mathrm{NH}_{3}$-SCR catalysts with $\mathrm{SO}_{2}$ tolerance and regeneration ability.

\section{Experimental details}

\subsection{Preparation of catalysts}

Typically, MIL-101(Cr) was prepared by reacting terephthalic acid (332 mg, $2.0 \mathrm{mmol})$ with $\mathrm{Cr}\left(\mathrm{NO}_{3}\right)_{3} \cdot 9 \mathrm{H}_{2} \mathrm{O}(800 \mathrm{mg}, 2.0 \mathrm{mmol})$ and de-ionized water $(9.5 \mathrm{~mL})$ at $220^{\circ} \mathrm{C}$ for $8 \mathrm{~h}$. Microcrystalline green powders of MIL-101(Cr) were produced during the reaction. The obtained powders were washed by ammonium hydroxide, water, and ethanol, in sequence, 3 times each. The powders were dried and calcined at a certain temperature for $4 \mathrm{~h}$ under $\mathrm{N}_{2}$ flow, and the heating rate was set at $1^{\circ} \mathrm{C} \min ^{-1}$. Finally, the cooled sample was exposed to air and denoted as $\mathrm{Cr}_{2} \mathrm{O}_{3} / \mathrm{C}-X$, in which $X$ represents the calcining temperature.

As reported in ref. 44, a $\mathrm{Cr}_{2} \mathrm{O}_{3}$ sample was obtained by calcining $\mathrm{Cr}\left(\mathrm{NO}_{3}\right)_{3} \cdot 9 \mathrm{H}_{2} \mathrm{O}$ at $450{ }^{\circ} \mathrm{C}$ for $4 \mathrm{~h}$. $\mathrm{MnO}_{2}$ was purchased from Aladdin and was used without further purification. An active carbon supported $\mathrm{Cr}_{2} \mathrm{O}_{3}$ catalyst was synthesized through a wetness impregnation process. Active carbon $(1.00 \mathrm{~g})$ was dispersed into de-ionized water $(50 \mathrm{~mL})$ containing $\mathrm{Cr}\left(\mathrm{NO}_{3}\right)_{3} \cdot 9 \mathrm{H}_{2} \mathrm{O}(9.92 \mathrm{~g})$. The turbid solution was oil-bath heated at $110{ }^{\circ} \mathrm{C}$ until the water was totally evaporated. The dried powders were calcined at $450{ }^{\circ} \mathrm{C}$ for $4 \mathrm{~h}$ under a $\mathrm{N}_{2}$ flow and the obtained sample was noted as $\mathrm{Cr}_{2} \mathrm{O}_{3} / \mathrm{C}-\mathrm{WI}$.

\subsection{Characterizations}

The X-ray diffraction (XRD) patterns of the catalysts were studied using an XRD-6000 X-ray diffractometer (Shimadzu). Xray fluorescence (XRF) analysis was performed on an ARL-900 Xray fluorescence analyzer. FTIR analysis was carried out using a NEXUS870 spectrometer (NICOLET, America). Raman spectra were measured at a resolution of $<1 \mathrm{~cm}^{-1}$ using a JY Labram HR 800 spectrophotometer equipped with an argon-ion laser source and an air-cooled CCD detector. $\mathrm{N}_{2}$ adsorption/desorption isotherms of the catalysts were obtained at $-196{ }^{\circ} \mathrm{C}$ using an ASAP2020 physical adsorption instrument (Micromeritics) to calculate the BET surface area of the catalysts. TEM analysis was performed on a double-aberration corrected Titan ${ }^{\mathrm{TM}}$ cubed G2 60-300 S/TEM equipped with Super-X ${ }^{\mathrm{TM}}$ technology. X-ray energy dispersive spectroscopy (EDS) mappings were acquired using the Super-X EDS system, which is composed of four silicon drift detectors covering $0.7 \mathrm{~s}$ rad collection.

$\mathrm{NH}_{3}$-temperature programmed desorption ( $\left.\mathrm{NH}_{3}-\mathrm{TPD}\right)$ experiments were performed using a multifunction chemisorption analyzer, equipped with a thermal conductivity detector (TCD). Samples were pretreated under a $\mathrm{NH}_{3}-\mathrm{N}_{2}$ flow $\left(\mathrm{NH}_{3} 1 \%\right)$ at $150{ }^{\circ} \mathrm{C}$ for $1 \mathrm{~h}$ and were heated under $\mathrm{N}_{2}$ flow; the heating rate was set at $10{ }^{\circ} \mathrm{C} \mathrm{min}^{-1}$.

$\mathrm{O}_{2}$-temperature programmed desorption $\left(\mathrm{O}_{2}\right.$-TPD) experiments were performed using a multifunction chemisorption analyzer, equipped with a thermal conductivity detector (TCD). Samples were pretreated under $\mathrm{O}_{2}-\mathrm{He}$ flow $\left(\mathrm{O}_{2} 25 \%\right)$ at $25{ }^{\circ} \mathrm{C}$ for $1 \mathrm{~h}$ and were heated under a He flow; the heating rate was set at $10{ }^{\circ} \mathrm{C} \mathrm{min}{ }^{-1}$.

$\mathrm{H}_{2}$-temperature programmed reduction $\left(\mathrm{H}_{2}\right.$-TPR) of the catalysts was recorded using a chemisorption analyzer. Samples were pretreated under a $\mathrm{N}_{2}$ flow at $200{ }^{\circ} \mathrm{C}$ for $1 \mathrm{~h}$, and were 
heated under a $\mathrm{H}_{2}-\mathrm{Ar}$ flow $\left(\mathrm{H}_{2}, 7 \%\right)$; the heating rate was set at $10{ }^{\circ} \mathrm{C} \min ^{-1}$.

X-ray photoelectron spectroscopy (XPS) measurements were performed using a PHI 5000 VersaProbe spectrophotometer. The contents of the metal ions were measured via an inductive coupled plasma emission spectrometer (Optima 5300DV, PE). Energy referencing was accomplished by setting the adventitious carbon peak to $284.6 \mathrm{eV}$. The ex situ XPS details are described below. The sample was treated under a certain atmosphere for a certain time in a reaction chamber connected with the intro chamber of the XPS instrument. Following this, the reaction chamber was vacuumized and the treated sample was transferred to the XPS instrument without exposure to air.

The in situ DRIFT experiments were performed on a Nicolet Nexus 5700 FTIR spectrometer using a diffuse reflectance attachment (HARRICK) equipped with a reaction cell ( $\mathrm{ZnSe}$ windows). The number of scans was 32 at a resolution of $4 \mathrm{~cm}^{-1}$ and the spectra were presented as Kubelka-Munk function, referred to the background spectra of the recorded catalyst in $\mathrm{N}_{2}$.

\subsection{NO oxidation tests}

The NO oxidation tests were performed in a fixed-bed reactor with $0.2 \mathrm{~g}$ catalyst. The feed gas contained $500 \mathrm{ppm}$ NO and 5 vol\% $\mathrm{O}_{2}$ with $\mathrm{N}_{2}$ as the balance gas. The total flow rate of the feed gas was $100 \mathrm{~mL} \mathrm{~min}{ }^{-1}$, corresponding to a space velocity of approximately $30000 \mathrm{~h}^{-1}$. Including $\mathrm{NO}$ and $\mathrm{NO}_{2}$, the effluent gases were continuously analyzed at $150{ }^{\circ} \mathrm{C}$ by an online Thermofisher IS10 FTIR spectrometer equipped with a $2 \mathrm{~m}$ pathlength gas cell (250 $\mathrm{mL}$ volume).

\section{4. $\mathrm{NH}_{3}$-SCR activity, $\mathrm{SO}_{2}$ poisoning, and regeneration tests}

The $\mathrm{NH}_{3}$-SCR activity tests were performed in a fixed-bed reactor with $0.2 \mathrm{~g}$ catalyst. The feed gas contained $500 \mathrm{ppm} \mathrm{NO}$, $500 \mathrm{ppm} \mathrm{NH} \mathrm{NH}_{3}, 5$ vol\% $\mathrm{O}_{2}, 50 \mathrm{ppm} \mathrm{SO}_{2}$ (when used), 5 vol\% $\mathrm{H}_{2} \mathrm{O}$ (when used) and $\mathrm{N}_{2}$ as the balance gas. The total flow rate of the feed gas was $100 \mathrm{~mL} \mathrm{~min}{ }^{-1}$, corresponding to a space velocity of approximately $30000 \mathrm{~h}^{-1}$. $\mathrm{SO}_{2}$ poisoning and regeneration tests of catalysts were carried out at $150{ }^{\circ} \mathrm{C}$. Including $\mathrm{NO}, \mathrm{NH}_{3}, \mathrm{NO}_{2}$, and $\mathrm{N}_{2} \mathrm{O}$, the effluent gases were continuously analyzed at $150{ }^{\circ} \mathrm{C}$ using an online Thermofisher IS10 FTIR spectrometer equipped with a $2 \mathrm{~m}$ path-length gas cell ( $250 \mathrm{~mL}$ volume).

\subsection{Regeneration of $\mathrm{SO}_{2}$ poisoned catalysts}

$\mathrm{SO}_{2}$ poisoned catalysts were regenerated at $300{ }^{\circ} \mathrm{C}$ for $30 \mathrm{~min}$, and then were cooled down to room temperature. All the heat treatments were carried out under $\mathrm{N}_{2}$ atmosphere.

The sulfating of metal oxide catalysts during $\mathrm{SO}_{2}$ poisoning was investigated by inductively coupled plasma-emission spectroscopy (ICP).

The $\mathrm{SO}_{2}$-poisoned catalyst $(0.2 \mathrm{~g})$ was washed with deionized water for 5 times. The eluate was collected and diluted to $50 \mathrm{~mL}$. The diluted eluate was investigated by ICP analysis. The contents of metal sulfate $m_{\mathrm{MSO}_{4}}$ were calculated using the equation below.

$$
m_{\mathrm{MSO}_{4}}=\frac{m_{\mathrm{M}^{n+}} \times 0.05 L \times M_{\mathrm{MSO}_{4}}}{M_{\mathrm{M}}}
$$

where, $m_{\mathrm{M}^{n+}}$ is the content of the metal ion, $M_{\mathrm{MSO}_{4}}$ was obtained via ICP analysis and $M_{\mathrm{M}}$ is the molar mass of metal sulfate, which also corresponds to the molar mass of the metal ion.

For Cr oxide, $m_{\mathrm{Cr}_{2}\left(\mathrm{SO}_{4}\right)_{3}}=m_{\mathrm{Cr}^{3+}} \times 0.188$

For Mn oxide, $m_{\mathrm{MnSO}_{4}}=m_{\mathrm{Mn}^{2+}} \times 0.137$

\section{Results and discussion}

\section{1. $\mathrm{NH}_{3}$-SCR performance, $\mathrm{SO}_{2}$ tolerance, and regeneration}

The $\mathrm{NH}_{3}$-SCR activities of the $\mathrm{CrO}_{x}$ samples derived from various precursors and $\mathrm{MnO}_{2}$ are shown in Fig. 1 and $\mathrm{S} 1 \uparrow$. As it was anticipated, all the catalysts derived from MIL-101 exhibited superior activities than pure $\mathrm{Cr}_{2} \mathrm{O}_{3}$. Remarkably, $\mathrm{CrO}_{x} / \mathrm{C}-450$, parallel to $\mathrm{MnO}_{2}$, exhibited a wide operation temperature window from $125{ }^{\circ} \mathrm{C}$ to $200{ }^{\circ} \mathrm{C}$. The activity of $\mathrm{Cr}_{2} \mathrm{O}_{3} / \mathrm{C}-\mathrm{WI}$ was enhanced compared with pure $\mathrm{Cr}_{2} \mathrm{O}_{3}$, while it was much lower than $\mathrm{CrO}_{x} / \mathrm{C}-450$. This extraordinarily low temperature $\mathrm{NH}_{3}$-SCR performance makes $\mathrm{CrO}_{x} / \mathrm{C}-450$ the best catalyst among all the samples derived from MIL-101. To evaluate the $\mathrm{NH}_{3}$-SCR performances on the catalysts more precisely, the normalized rates per mole transition metal were calculated and the results are displayed in Fig. 2a. The catalytic activity order is $\mathrm{CrO}_{x} / \mathrm{C}-450>\mathrm{Mn}_{2} \mathrm{O}_{3}>\mathrm{Cr}_{2} \mathrm{O}_{3} / \mathrm{C}-\mathrm{WI}>$ $\mathrm{Cr}_{2} \mathrm{O}_{3}$. In addition, the apparent active energies of $\mathrm{CrO}_{x} / \mathrm{C}-450$ and $\mathrm{Cr}_{2} \mathrm{O}_{3}$ based catalysts were obtained when NO conversions were limited to low conversion (Fig. $2 \mathrm{~b}$ and Table $\mathrm{S} 2 \dagger$ ). The apparent active energy of $\mathrm{NH}_{3}$-SCR on the $\mathrm{CrO}_{x} / \mathrm{C}-450$ catalyst was lower than those of SCR on $\mathrm{Cr}_{2} \mathrm{O}_{3} / \mathrm{C}$-WI and $\mathrm{Cr}_{2} \mathrm{O}_{3}$, which further confirms the superb catalytic activity of the $\mathrm{CrO}_{x} / \mathrm{C}-450$ sample. Based on the kinetics data listed in Tables $\mathrm{S} 3$ and $\mathrm{S} 4, \dagger$ apparent kinetics equations of $\mathrm{NH}_{3}$-SCR on $\mathrm{CrO}_{x} / \mathrm{C}-450$ and $\mathrm{Cr}_{2} \mathrm{O}_{3} / \mathrm{C}$-WI catalysts were obtained (Fig. $\mathrm{S} 2 \dagger$ ). For $\mathrm{CrO}_{x} / \mathrm{C}-450, r=\left[\mathrm{NH}_{3}\right]^{0.586}[\mathrm{NO}]^{0.964}$ at $150{ }^{\circ} \mathrm{C}$, while for $\mathrm{Cr}_{2} \mathrm{O}_{3} / \mathrm{C}-\mathrm{WI}, r=\left[\mathrm{NH}_{3}\right]^{0.433}[\mathrm{NO}]^{0.092}$. The different reaction rate equations of $\mathrm{NH}_{3}$-SCR on $\mathrm{CrO}_{x} / \mathrm{C}-450$ and $\mathrm{Cr}_{2} \mathrm{O}_{3} / \mathrm{C}-\mathrm{WI}$ catalysts indicated their different reaction mechanisms, which may result in different $\mathrm{NH}_{3}$-SCR performance of $\mathrm{CrO}_{x}$ / C-450 and $\mathrm{Cr}_{2} \mathrm{O}_{3} / \mathrm{C}$-WI catalysts. The $\mathrm{N}_{2}$ selectivity of $\mathrm{CrO}_{x} / \mathrm{C}$ 450 remained at a high level (over 90\%) in its operation temperature window, while those of $\mathrm{Cr}_{2} \mathrm{O}_{3}$ and $\mathrm{MnO}_{2}$ were very poor. This indicated that side reactions such as the formation of $\mathrm{N}_{2} \mathrm{O}$ hardly occurred on the $\mathrm{CrO}_{x} / \mathrm{C}-450$ catalyst. $\mathrm{SO}_{2}-$ and $\mathrm{H}_{2} \mathrm{O}$-tolerance of $\mathrm{CrO}_{x} / \mathrm{C}-450$ was further tested and the results are presented in Fig. $1 \mathrm{c}$ and $\mathrm{S} 1 \mathrm{c} . \dagger \mathrm{CrO}_{x} / \mathrm{C}-450$ exhibited over $80 \%$ NO conversion within $24 \mathrm{~h}$ in the presence of $\mathrm{H}_{2} \mathrm{O}$, indicating its satisfactory water tolerance. When $\mathrm{SO}_{2}$ was introduced into the feed gas, the activity of $\mathrm{CrO}_{x} / \mathrm{C}$ 450 gradually dropped to $60 \%$ within $20 \mathrm{~h}$, while it dropped to $50 \%$ in $20 \mathrm{~h}$ when $\mathrm{SO}_{2}$ and $\mathrm{H}_{2} \mathrm{O}$ co-existed in the feed gas. The activity of $\mathrm{CrO}_{x} / \mathrm{C}-450$ could be recovered after a heat treatment at a temperature as low as $300{ }^{\circ} \mathrm{C}$. This indicated that the poisoning effect of $\mathrm{SO}_{2}$ on $\mathrm{CrO}_{x} / \mathrm{C}-450$ could be accelerated by $\mathrm{H}_{2} \mathrm{O}$, while $\mathrm{H}_{2} \mathrm{O}$ hardly influenced the regeneration ability of $\mathrm{CrO}_{x} / \mathrm{C}-450$. In contrast, the $\mathrm{MnO}_{2}$ catalyst 

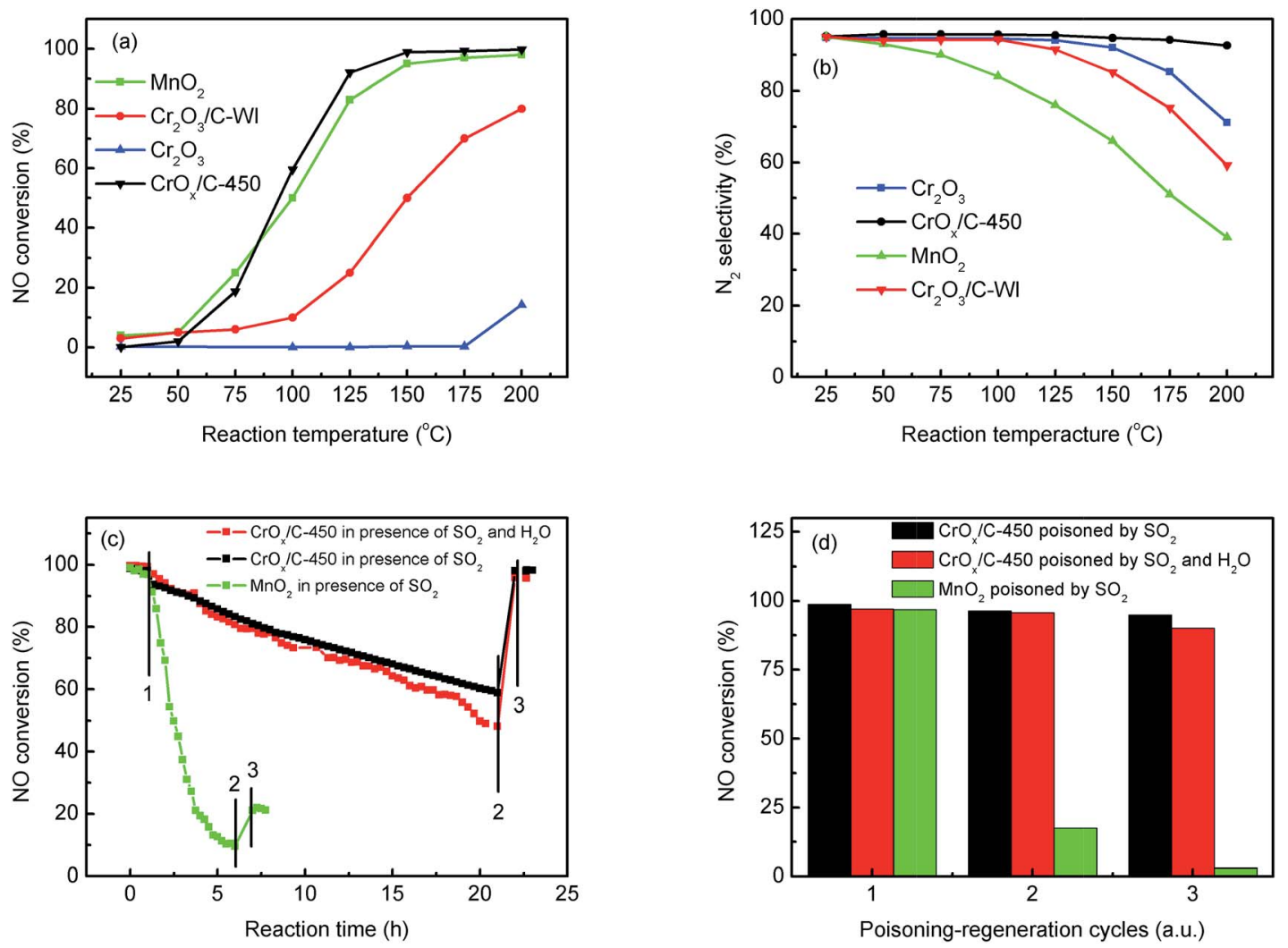

Fig. $1 \mathrm{NH}_{3}$-SCR activity of catalysts: (a) $\mathrm{NO}$ conversion, (b) $\mathrm{N}_{2}$ selectivity, (c) $\mathrm{SO}_{2}$ poisoning test (step 1, 2, and 3 present $\mathrm{SO}_{2}$ and $\mathrm{H}_{2} \mathrm{O}$ (when used) on, $\mathrm{SO}_{2}$ and $\mathrm{H}_{2} \mathrm{O}$ (when used) off, and after regeneration), and (d) regeneration ability.

deactivated rapidly upon $\mathrm{SO}_{2}$ introduction in $6 \mathrm{~h}$, and this process was irreversible. It was demonstrated that the $\mathrm{CrO}_{x} / \mathrm{C}-$ 450 catalyst has satisfactory $\mathrm{SO}_{2}$-tolerance. The regeneration ability of $\mathrm{CrO}_{x} / \mathrm{C}-450$ was further studied. As shown in Fig. 1d, over $90 \%$ of the catalytic activity of $\mathrm{CrO}_{x} / \mathrm{C}-450$ could be recovered as compared to that of the fresh catalyst after 3 poisoning-regeneration cycles irrespective of whether $\mathrm{H}_{2} \mathrm{O}$ was introduced by regeneration at $300{ }^{\circ} \mathrm{C}$ in flowing $\mathrm{N}_{2}$, while that of $\mathrm{MnO}_{2}$ catalyst dropped dramatically through only 1 poisoning-regeneration cycle, which indicated the remarkable regeneration ability of the $\mathrm{CrO}_{x} / \mathrm{C}-450$ sample.

\subsection{Structural information}

To investigate the $\mathrm{NH}_{3}$-SCR on the catalysts, the structural information of catalysts was necessary. XRD, XRF, FTIR, Raman, and TEM analyses were carried out to investigate the structural properties of the catalysts synthesized from MIL$101(\mathrm{Cr})$. The XRD patterns of all samples are shown in Fig. S3. $\dagger$ In the XRD pattern of the precursor, sharp and distinct peaks attributed to the MIL-101 phase were detected, which is in agreement with the data reported by Jhung et al. ${ }^{43}$ When MIL101 was heated in $\mathrm{N}_{2}$-flow, the XRD peaks of MIL-101 became weak and gradually disappeared with an increase in
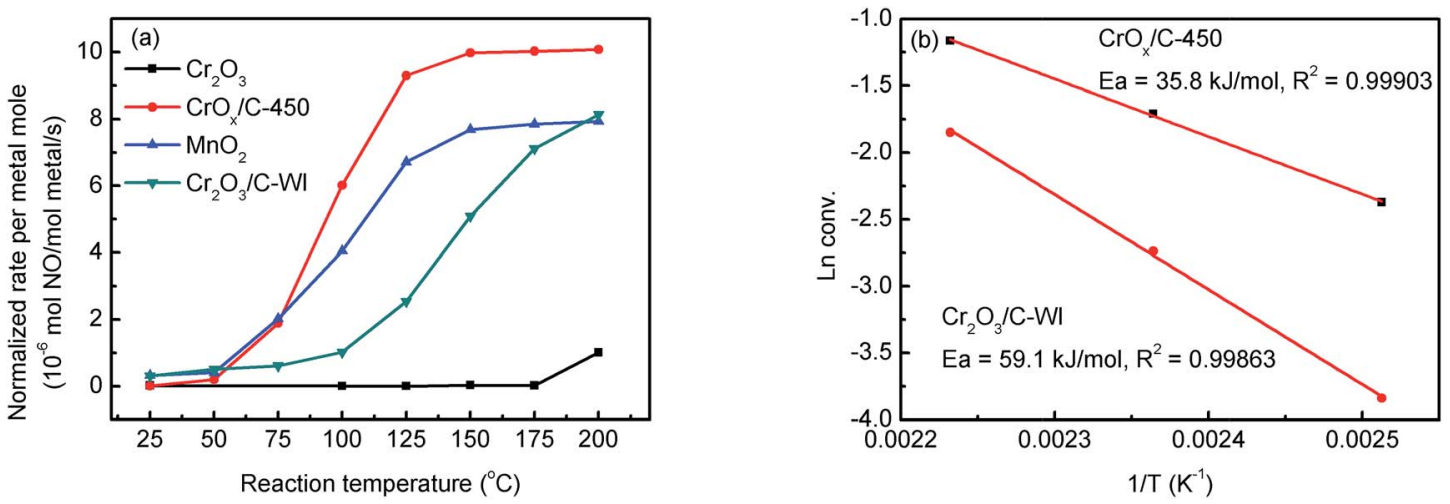

Fig. 2 (a) Normalized rates per metal mole of catalysts, (b) apparent active energy of $\mathrm{CrO}_{x} / \mathrm{C}-450$ and $\mathrm{Cr}_{2} \mathrm{O}_{3} / \mathrm{C}-\mathrm{WI}$ catalysts. 
temperature. When the calcining temperature reached $450{ }^{\circ} \mathrm{C}$, the peaks of the MIL-101 phase disappeared completely and replaced with wide and weak peaks at $24.5^{\circ}, 33.5^{\circ}$, and $36.1^{\circ}$, which belonged to the (012), (104), and (110) plane, respectively, of the eskolaite phase (PDF\#38-1479) as well as $\mathrm{Cr}_{2} \mathrm{O}_{3} / \mathrm{C}-\mathrm{WI}{ }^{45}$ This indicated that the MIL-101 structure could be destroyed through the calcining process, accompanied with the formation of the eskolaite phase. Furthermore, the $\mathrm{CrO}_{x} / \mathrm{C}-450$ sample was found to have a small particle size based on its broad XRD peaks.

FTIR and Raman analyses were carried out to study the carbon species in the catalysts. As shown in Fig. S4a, $\uparrow$ the bands at $3300 \mathrm{~cm}^{-1}, 1600 \mathrm{~cm}^{-1}$, and $1400 \mathrm{~cm}^{-1}$ were identified in the FTIR spectra of MIL-101. The broad band at $3300 \mathrm{~cm}^{-1}$ arises due to the stretching vibration of the surface $-\mathrm{OH}$ groups. The two bands at 1600 and $1400 \mathrm{~cm}^{-1}$ could be attributed to the stretching vibration of the -COO group of the organic linkers of MIL-101. However, the intensity of bands at $1600 \mathrm{~cm}^{-1}$ and $1400 \mathrm{~cm}^{-1}$ decreased on increasing the calcination temperature. This indicates that the organic linker begins to decompose and carbonize when the calcining temperature increases. The carbonization process was further investigated by Raman analysis (Fig. S4b $\dagger$ ). Wide bands at 1360 and $1590 \mathrm{~cm}^{-1}$, corresponding to the D-band and G-band of MIL-101, were detected in the samples calcined at low temperatures, such as 350 and $400{ }^{\circ} \mathrm{C}$. When the calcining temperature increased, the Gband gradually disappeared and the D-band still remained, which indicated the loss of the ordered structure of MOFs and the formation of amorphous carbon. In the spectrum of Cr-550, the G-band disappeared absolutely and only a wide D-band was observed. This illustrates that the organic linker carbonized and transformed to amorphous carbon during the calcining process, which accompanied with the destruction of the MOFs structure.

The elemental contents of catalysts were studied via XRF analysis. Since the organic species in MIL-101 completely transformed to amorphous carbon in $\mathrm{CrO}_{x} / \mathrm{C}-450$, as mentioned before, the ignition loss in XRF analysis of $\mathrm{CrO}_{x} / \mathrm{C}-450$ was believed to be the result of carbon species burning. Thus, the elemental contents of the catalysts could be calculated from the XPF data and the results are shown in Table 1 . The $\mathrm{CrO}_{x} / \mathrm{C}-450$ catalyst consisted of $19.2 \% \mathrm{Cr}, 28.7 \% \mathrm{O}$, and $52.0 \% \mathrm{C}$. As it was designed, the elemental contents of $\mathrm{Cr}_{2} \mathrm{O}_{3} / \mathrm{C}-\mathrm{WI}$ were similar to those of $\mathrm{CrO}_{x} / \mathrm{C}-450$.
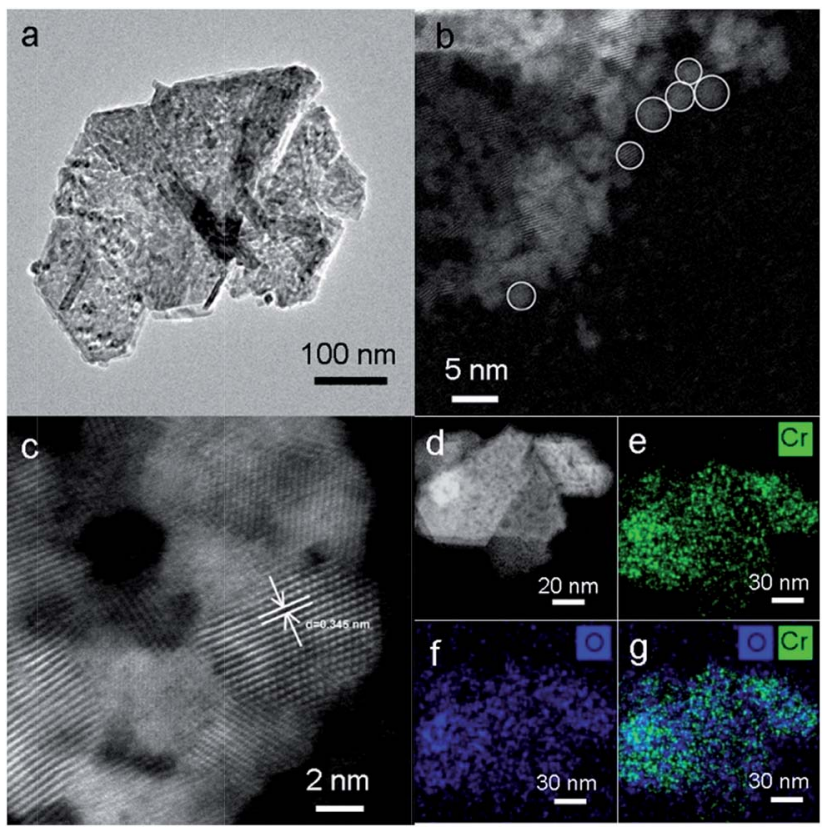

d'olyess e

$\mathrm{Cr}$

Fig. 3 (a) TEM image, (b-d) high resolution HAADF-STEM image of $\mathrm{CrO}_{x} / \mathrm{C}-450$ catalyst. (e, f) 2D STEM EDS elemental maps of $\mathrm{Cr}-\mathrm{K} \alpha$ (Green) and $O$ (Blue) elements, respectively. (g) A superimposed image of (e) and (f).

TEM analysis was performed to investigate the structure of MIL-101, $\mathrm{CrO}_{x} / \mathrm{C}-450$, and $\mathrm{Cr}_{2} \mathrm{O}_{3} / \mathrm{C}-\mathrm{WI}$. As shown in Fig. S5a, $\dagger$ the MIL-101 with octahedron morphology can be observed distinctly, while it transformed to a hexagonal sheet after calcination (Fig. 3a). Further structural information was obtained via high-angle annual dark field (HAADF) imaging (Fig. 3b). The hexagonal-like sample observed in Fig. 3a was actually an aggregation of nano-particles with an average size of $3 \mathrm{~nm}$. In addition, lattice fringes of $d=0.345 \mathrm{~nm}$ were observed (Fig. 3c), corresponding to the eskolaite $\mathrm{Cr}_{2} \mathrm{O}_{3}$ (012) crystal plane, which further confirmed that the $\mathrm{Cr}$ oxide in the $\mathrm{CrO}_{x} / \mathrm{C}$ 450 catalyst has the eskolaite phase. From the EDX element mapping analysis (Fig. 3e-g), Cr element and $\mathrm{O}$ element were observed to be highly dispersed in the $\mathrm{CrO}_{x} / \mathrm{C}-450$ sample and the superimposed image of $\mathrm{Cr}$ and $\mathrm{O}$ matches the HAADF image. It was estimated that the $\mathrm{CrO}_{x} / \mathrm{C}-450$ catalyst was primarily formed by $\mathrm{CrO}_{x}$ nano-particles with eskolaite phase as

Table 1 Element contents and surface areas of catalysts

\begin{tabular}{|c|c|c|c|c|c|c|c|c|}
\hline \multirow[b]{2}{*}{ Sample } & \multicolumn{2}{|c|}{ Contents $^{a}(\mathrm{wt} \%)$} & \multicolumn{3}{|c|}{ Elements contents (at\%) } & \multicolumn{3}{|c|}{ Surface $\operatorname{area}^{b}\left(\mathrm{~m}^{2} \mathrm{~g}^{-1}\right.$ catalyst $)$} \\
\hline & $\mathrm{Cr}_{2} \mathrm{O}_{3}$ & $\begin{array}{l}\text { Ignition } \\
\text { loss }\end{array}$ & $\mathrm{Cr}$ & $\mathrm{O}$ & $\mathrm{C}$ & Sample & Carbon support $^{c}$ & Active material \\
\hline $\mathrm{CrO}_{x} / \mathrm{C}-450$ & 70.2 & 29.8 & 19.2 & 28.7 & 52.0 & 256 & 784 & 20.8 \\
\hline $\mathrm{Cr}_{2} \mathrm{O}_{3} / \mathrm{C}-\mathrm{WI}$ & 69.5 & 30.5 & 18.9 & 28.4 & 52.7 & 279 & 897 & 9.9 \\
\hline $\mathrm{Cr}_{2} \mathrm{O}_{3}$ & 99.9 & 0.1 & 40.0 & 60.0 & - & 28 & - & - \\
\hline
\end{tabular}

${ }^{a}$ Contents of catalysts were obtained from XRF analyses. ${ }^{b}$ Surface areas of catalysts were obtained from $\mathrm{N}_{2}$ adsorption/desorption analyses. ${ }^{c}$ Carbon support of $\mathrm{CrO}_{x} / \mathrm{C}-450$ catalyst was obtained by washing $\mathrm{CrO}_{x} / \mathrm{C}-450$ using hydrochloric acid. Carbon support of $\mathrm{Cr}_{2} \mathrm{O}_{3} / \mathrm{C}-\mathrm{WI}$ is active carbon. 
designed in this study. The $\mathrm{CrO}_{x} / \mathrm{C}-450$ sample after 3 poisoning-regeneration cycles was also imaged to investigate the stability of the catalyst (Fig. S5b $\dagger$ ). The used sample was primarily composed of $\mathrm{CrO}_{x}$ nano-particles, similar to the fresh sample, and no major difference in the particle size of $\mathrm{Cr}_{2} \mathrm{O}_{3}$ could be observed after 5 deactivation-regeneration circles, which evidently proved the stability of the sample $\mathrm{CrO}_{x} / \mathrm{C}-450$. $\mathrm{Cr}_{2} \mathrm{O}_{3}$ and $\mathrm{Cr}_{2} \mathrm{O}_{3} / \mathrm{C}-\mathrm{WI}$, however, had a bulk-like shape (Fig. S5c and $\mathrm{d}_{\dagger} \dagger$ ) with average particle sizes of over $100 \mathrm{~nm}$. In the structure of the MIL-101 precursor, metal nodes containing $3 \mathrm{Cr}$ atoms were covered by organic linkers. Therefore, it is reasonable to suggest that $\mathrm{CrO}_{x}$ nano-particles in the $\mathrm{CrO}_{x} / \mathrm{C}$ 450 catalyst stabilized by covering carbon species transformed from organic linkers of MIL-101 after the calcining process.

The feasible mechanism of catalyst synthesis is displayed in Fig. 4. During the calcination process, organic linkers covering Cr nodes carbonized and the structure of MIL-101 gradually destroyed. The amorphous carbon from organic linkers limited the growth of Cr nodes. Finally, when the calcined sample was exposed to air, the remaining Cr nano-particles were oxidized to $\mathrm{CrO}_{x}$ nano-particles with eskolaite phase, forming the structure of amorphous carbon covered $\mathrm{CrO}_{x}$ nano-particles $\left(\mathrm{CrO}_{x} / \mathrm{C}\right)$.

\subsection{Textural properties of catalysts}

As mentioned before, the $\mathrm{CrO}_{x} / \mathrm{C}-450$ catalyst was primarily formed by $\mathrm{CrO}_{x}$ nano-particles with eskolaite phase and exhibited enhanced $\mathrm{NH}_{3}$-SCR activity and satisfying regeneration ability. To explore the relationship between the structure of $\mathrm{CrO}_{x} / \mathrm{C}-450$ and the $\mathrm{NH}_{3}$-SCR performance, the properties of the catalysts were characterized by BET, XPS, $\mathrm{H}_{2}-\mathrm{TPR}, \mathrm{O}_{2}$-TPD, and $\mathrm{NH}_{3}$-TPD analyses.

The surface areas of the catalysts can influence the number of active sites on the catalyst surface, which is considered as an important fact affecting the catalytic activity of $\mathrm{NH}_{3}$-SCR catalysts. The surface areas of $\mathrm{CrO}_{x} / \mathrm{C}-450, \mathrm{Cr}_{2} \mathrm{O}_{3}$, and $\mathrm{Cr}_{2} \mathrm{O}_{3} / \mathrm{C}-\mathrm{WI}$ obtained from BET analysis are listed in Table 1. The BET surface areas of $\mathrm{CrO}_{x} / \mathrm{C}-450$ and $\mathrm{Cr}_{2} \mathrm{O}_{3} / \mathrm{C}-\mathrm{WI}$ are similar and larger than that of $\mathrm{Cr}_{2} \mathrm{O}_{3}$. Due to the enhanced $\mathrm{NH}_{3}-\mathrm{SCR}$
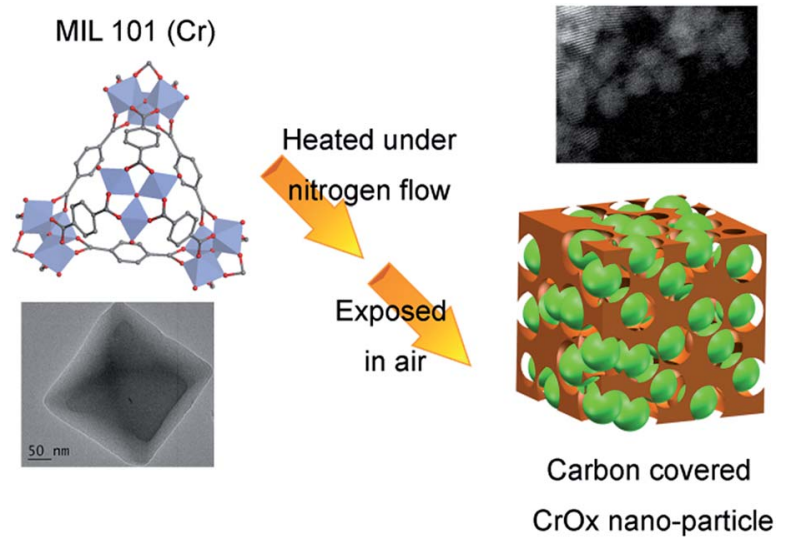

Fig. 4 Possible mechanism of catalyst synthesis (green spheres present $\mathrm{CrO}_{x}$ nano-particles, brown skolen present amorphous carbon). performances of $\mathrm{CrO}_{x} / \mathrm{C}-450$ and $\mathrm{Cr}_{2} \mathrm{O}_{3} / \mathrm{C}$-WI (Fig. 1), it is believed that the enlarged surface area increased the activity of the Cr oxide catalyst. According to the reaction rates normalized by the surface areas of the active material of the catalysts, $\mathrm{CrO}_{x} /$ C-450 exhibited comparatively superior NO conversion than $\mathrm{Cr}_{2} \mathrm{O}_{3} / \mathrm{C}$-WI at $125^{\circ} \mathrm{C}$ and $150^{\circ} \mathrm{C}$. This infers that a large surface area is not the only reason for the excellent $\mathrm{NH}_{3}$-SCR activity of $\mathrm{CrO}_{x} / \mathrm{C}-450$.

The acidity of the catalysts, which can influence the absorption of reaction agents, is an important factor affecting the $\mathrm{NH}_{3}$-SCR performance of catalysts. This property of catalysts was investigated by $\mathrm{NH}_{3}$-TPD analysis. As displayed in Fig. S6a, $\dagger$ the $\mathrm{NH}_{3}$ desorption behaviours of $\mathrm{Cr}_{2} \mathrm{O}_{3}$ and $\mathrm{CrO}_{x} / \mathrm{C}-450$ were similar. No distinct $\mathrm{NH}_{3}$ desorption peak was observed from 150 to $400{ }^{\circ} \mathrm{C}$ in the profiles of both $\mathrm{Cr}_{2} \mathrm{O}_{3}$ and $\mathrm{CrO}_{x} / \mathrm{C}-450$ samples, which indicated the weak acidity of these two samples. Therefore, the giant $\mathrm{NH}_{3}$-SCR performance difference between $\mathrm{Cr}_{2} \mathrm{O}_{3}$ and $\mathrm{CrO}_{x} / \mathrm{C}$ is not the result of acidity.

The redox ability of materials is another significant factor influencing the catalytic activity of the $\mathrm{NH}_{3}$-SCR catalyst. $\mathrm{H}_{2}$ TPR method was utilized to discuss this property of the synthesized catalysts. As illustrated in Fig. $5 \mathrm{~b}, \mathrm{Cr}_{2} \mathrm{O}_{3}$ exhibited a single-peak profile. The $\mathrm{H}_{2}$ consumption peak at $343{ }^{\circ} \mathrm{C}$ was a result of one-step reduction from $\mathrm{Cr}^{6+}$ to $\mathrm{Cr}^{3+}$, accompanied by the loss of lattice oxygen atoms connected with $\mathrm{Cr}^{6+}$ ions. ${ }^{46}$ For
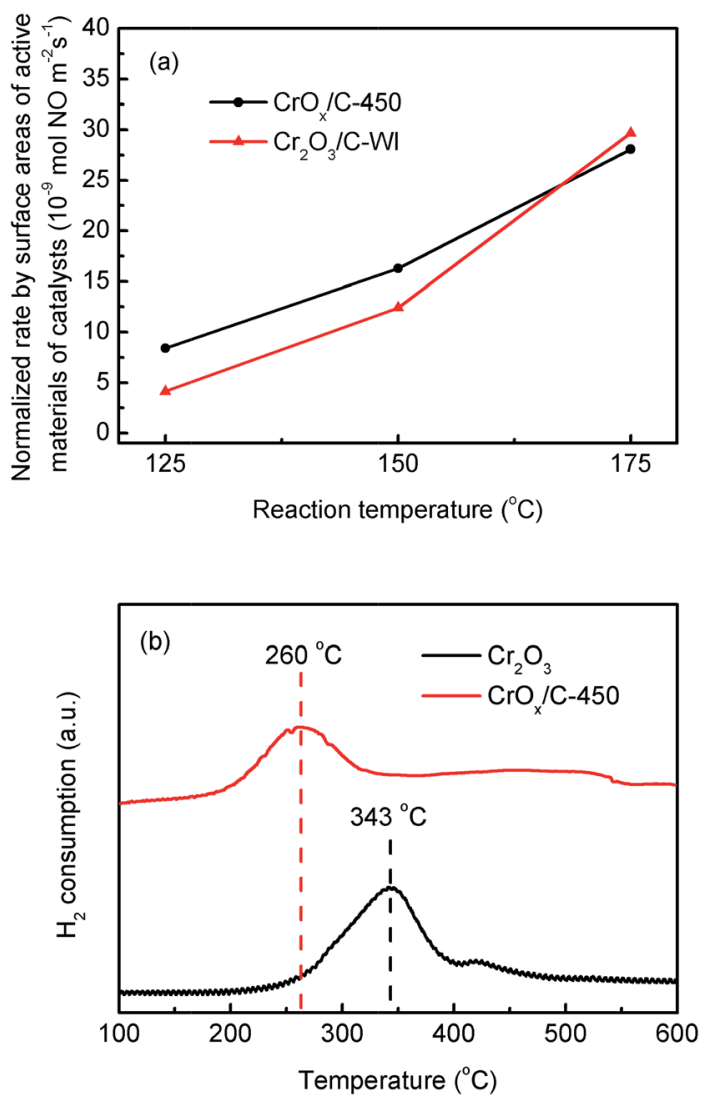

Fig. 5 (a) Normalized rates per surface areas of active material of $\mathrm{CrO}_{x} / \mathrm{C}-450$ and $\mathrm{Cr}_{2} \mathrm{O}_{3} / \mathrm{C}-\mathrm{Wl}$ catalysts, (b) $\mathrm{H}_{2}$-TPR result of $\mathrm{CrO}_{x} / \mathrm{C}$ 450 and bulk $\mathrm{Cr}_{2} \mathrm{O}_{3}$. 
the $\mathrm{CrO}_{x} / \mathrm{C}-450$ sample, the $\mathrm{H}_{2}$ consumption peak shifted to a low temperature, which indicated that $\mathrm{CrO}_{x} / \mathrm{C}-450$ exhibited stronger oxidation ability and a higher amount of active lattice oxygen than $\mathrm{Cr}_{2} \mathrm{O}_{3}$. In addition, $\mathrm{O}_{2}$-TPD analysis was carried out to investigate the stability of the oxygen atoms of the catalyst; the results are shown in Fig. S6b. $\dagger$ In the profile of $\mathrm{Cr}_{2} \mathrm{O}_{3}$, no $\mathrm{O}_{2}$ desorption peak was discovered in the temperature range from $50{ }^{\circ} \mathrm{C}$ to $450{ }^{\circ} \mathrm{C}$, which indicates that the oxygen on the surface of $\mathrm{Cr}_{2} \mathrm{O}_{3}$ is stable and inert. However, the curve of $\mathrm{CrO}_{x} / \mathrm{C}-450$ exhibited an $\mathrm{O}_{2}$ desorption peak from 200 to $350{ }^{\circ} \mathrm{C}$, which was much higher than the desorption temperature of absorbed $\mathrm{O}_{2}$ species recorded earlier. ${ }^{47}$ Hence, the desorption peak from 200 to $350{ }^{\circ} \mathrm{C}$ was believed to correspond to the dissociation of lattice oxygen from $\mathrm{CrO}_{x} / \mathrm{C}-450$. This demonstrates that the lattice oxygen of $\mathrm{CrO}_{x} / \mathrm{C}$ becomes more active and unstable than that of $\mathrm{Cr}_{2} \mathrm{O}_{3}$. Remarkably, the $\mathrm{CrO}_{x} / \mathrm{C}$ catalyst has high surface atom/lattice atom rate for its ultrasmall size as mentioned before. It is reasonable to conclude that the unsaturated surface atoms of $\mathrm{CrO}_{x} / \mathrm{C}$ cause the unique redox ability exhibited in $\mathrm{H}_{2}$ TPR analysis and the instability of the lattice oxygen atom detected in $\mathrm{O}_{2}$-TPD analysis. Unstable and activated oxygen atoms are inferred to enhance the activity of $\mathrm{CrO}_{x} / \mathrm{C}$ catalyst.

In XPS analysis, Cr 2p spectra (Fig. 6a) of all the samples were comparable. The $\mathrm{Cr} 2 \mathrm{p}_{3 / 2}$ peak could be divided into two peaks at $576.7 \mathrm{eV}$ and $578.6 \mathrm{eV}$, belonging to $\mathrm{Cr}^{3+}$ and $\mathrm{Cr}^{6+}$, respectively. ${ }^{48}$ The relative contents of $\mathrm{Cr}^{3+}$ and $\mathrm{Cr}^{6+}$ ions were analogous (Table 2), indicating their similar Cr state. The O 1s peak (Fig. 6b) could be separated into two peaks at $530.1 \mathrm{eV}$ and $531.9 \mathrm{eV}$, attributed to the lattice oxygen and surface $-\mathrm{OH}$ groups, respectively. ${ }^{49,50}$ The relative contents of these two types of oxygen species are also listed in Table 2. The $\mathrm{CrO}_{x} / \mathrm{C}-450$ sample exhibited more surface $-\mathrm{OH}$ groups than $\mathrm{Cr}_{2} \mathrm{O}_{3}$. Notably, the peak belonging to the lattice oxygen of $\mathrm{CrO}_{x} / \mathrm{C}-450$ shifts to the high binding energy side, contrasting with that of $\mathrm{Cr}_{2} \mathrm{O}_{3}$ and $\mathrm{Cr}_{2} \mathrm{O}_{3} / \mathrm{C}$-WI. It is evident that the lattice oxygen of $\mathrm{CrO}_{x} / \mathrm{C}-450$ carries less negative charge than $\mathrm{Cr}_{2} \mathrm{O}_{3}$ and $\mathrm{Cr}_{2} \mathrm{O}_{3} / \mathrm{C}$ WI. Materials with an ultrasmall size are deemed to have abundant dangling bands and their surface atoms are usually unsaturated-coordinated. In case of $\mathrm{CrO}_{x} / \mathrm{C}-450$, some surface oxygen atoms are inferred to be unsaturated coordinated for ultrasmall size of $\mathrm{CrO}_{x}$ nano-particles. This unsaturated oxygen is considered to have less negative charge and is expected to be more active than the saturated coordinated oxygen of bulk $\mathrm{Cr}_{2} \mathrm{O}_{3}$.

Furthermore, to determine whether the lattice oxygen participates in the $\mathrm{NH}_{3}$-SCR reaction, ex situ XPS analysis was carried out. The $\mathrm{CrO}_{x} / \mathrm{C}-450$ catalyst was heated under $\mathrm{NH}_{3}+\mathrm{NO}$ flow at $150{ }^{\circ} \mathrm{C}$ for $1 \mathrm{~h}$; the XPS spectra of $\mathrm{CrO}_{x} / \mathrm{C}-450$ before and after treatment are displayed in Fig. $6 \mathrm{c}$ and $\mathrm{d}$. In the $\mathrm{Cr} 2 \mathrm{p}$ spectra (Fig. 6c), the peak of $\mathrm{Cr}^{6+}$ at $578.6 \mathrm{eV}$ disappeared after $\mathrm{NH}_{3}+\mathrm{NO}$ treatment, while the peak of $\mathrm{Cr}^{3+}$ at $576.7 \mathrm{eV}$ enhanced. This infers that $\mathrm{Cr}^{6+}$ species on the surface of $\mathrm{CrO}_{x} / \mathrm{C}$
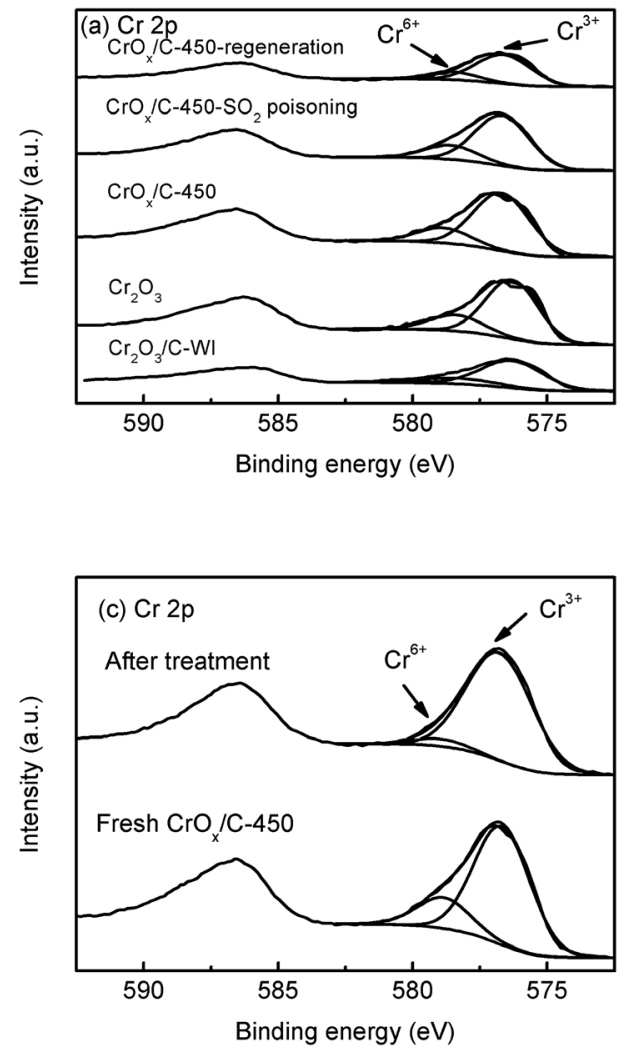
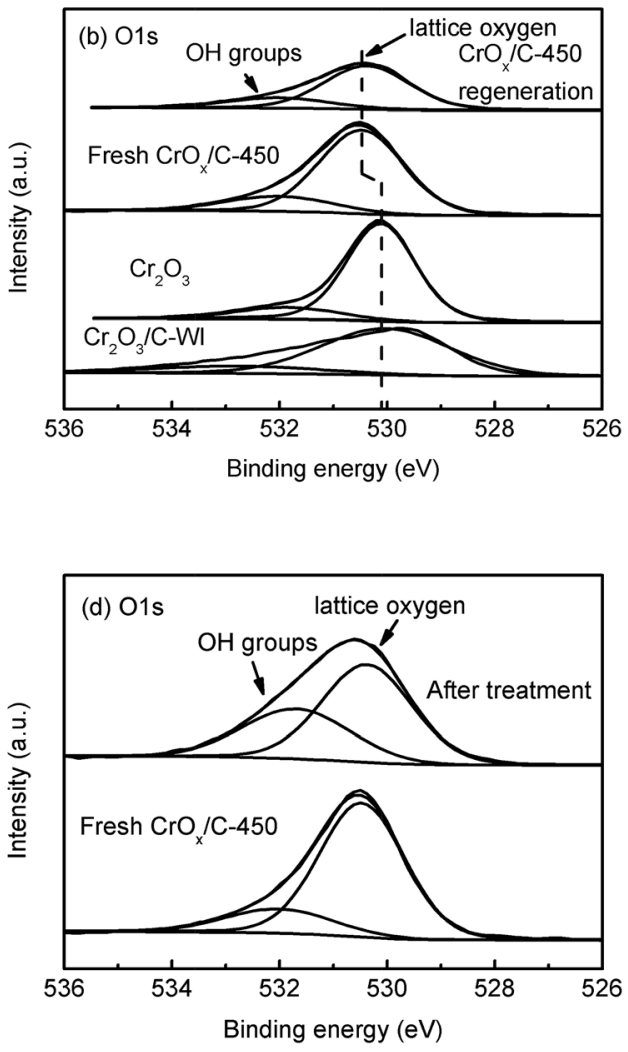

Fig. 6 XPS spectra of $\mathrm{Cr}_{2} \mathrm{O}_{3}$, fresh $\mathrm{CrO}_{x} / \mathrm{C}-450$ catalyst, $\mathrm{SO}_{2}$ poisoned $\mathrm{CrO}_{x} / \mathrm{C}-450$ catalyst, and regenerated $\mathrm{CrO} / \mathrm{C}-450$ catalyst: (a) $\mathrm{Cr} 2 \mathrm{p}$ spectra, (b) $\mathrm{O}$ 1s spectra, and ex situ XPS analysis of fresh $\mathrm{CrO}_{x} / \mathrm{C}-450$ catalyst and $\mathrm{CrO}_{x} / \mathrm{C}-450$ catalyst heated under $\mathrm{NH}_{3}+\mathrm{NO}$ flow at $150{ }^{\circ} \mathrm{C}$ for $1 \mathrm{~h}$ : (c) $\mathrm{Cr} 2 \mathrm{p}$ spectra, (d) $\bigcirc$ 1s. 
Table 2 Relative contents of $\mathrm{Cr}$ and $\mathrm{O}$ species on surfaces of catalysts

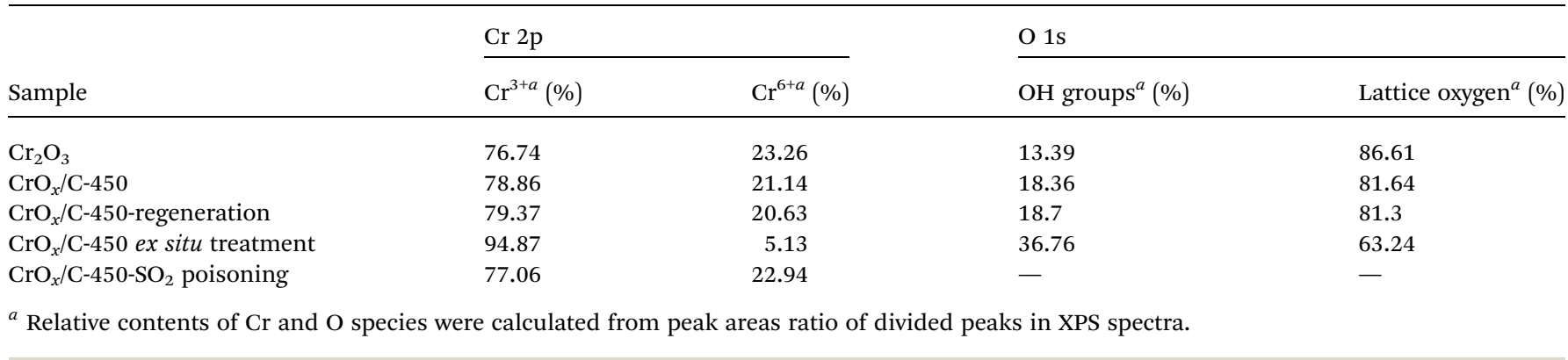

can react with the reagent molecules and eventually get consumed. Moreover, in the $\mathrm{O}$ 1s spectra (Fig. 6d), the peak intensity of lattice oxygen at $530.4 \mathrm{eV}$ decreased after treatment, while the intensity of the peak attributed to the surface $-\mathrm{OH}$ group at $531.7 \mathrm{eV}$ increased, which indicates the loss of surface lattice oxygen. Therefore, lattice oxygen was believed to take part in the $\mathrm{NH}_{3}-\mathrm{SCR}$ on the $\mathrm{CrO}_{x} / \mathrm{C}$ catalyst. Thus, $\mathrm{CrO}_{x} / \mathrm{C}-450$, which has more active lattice oxygen, can exhibit enhanced $\mathrm{NH}_{3}$-SCR activity than $\mathrm{Cr}_{2} \mathrm{O}_{3}$.

\subsection{Mechanism of $\mathrm{NH}_{3}$-SCR on $\mathrm{CrO}_{x} / \mathrm{C}$ catalyst}

In "fast $\mathrm{NH}_{3}$-SCR", $\mathrm{NO}$ catalytically reduced $\mathrm{NH}_{3}$ in assistance of $\mathrm{NO}_{2}$, which was reported to have lower activation energy and enhanced catalytic activity compared with the typical $\mathrm{NH}_{3}-\mathrm{SCR}$. Herein, the $\mathrm{CrO}_{x} / \mathrm{C}$ catalyst was proved to have activated lattice oxygen. It is reasonable to deduce that NO can be oxidized to $\mathrm{NO}_{2}$ by the activated oxygen on the $\mathrm{CrO}_{x} / \mathrm{C}$ surface, making the $\mathrm{NH}_{3}$-SCR on $\mathrm{CrO}_{x} / \mathrm{C}$ proceed as the "fast $\mathrm{NH}_{3}$-SCR" pathway. To verify this conjecture, $\mathrm{NO}$ oxidation on $\mathrm{CrO}_{x} / \mathrm{C}-450$ and $\mathrm{Cr}_{2} \mathrm{O}_{3} / \mathrm{C}$ WI catalysts was carried out. As displayed in Fig. 7a, NO could be oxidized to $\mathrm{NO}_{2}$ on both $\mathrm{CrO}_{x} / \mathrm{C}-450$ and $\mathrm{Cr}_{2} \mathrm{O}_{3} / \mathrm{C}-\mathrm{WI}$. However, the mass of formed $\mathrm{NO}_{2}$ on $\mathrm{CrO}_{x} / \mathrm{C}-450$ exceeded as compared to that on $\mathrm{Cr}_{2} \mathrm{O}_{3} / \mathrm{C}$-WI. Moreover, the normalized rate by surface area of $\mathrm{NO}$ oxidation on $\mathrm{CrO}_{x} / \mathrm{C}-450$ clearly surpassed that on $\mathrm{Cr}_{2} \mathrm{O}_{3} / \mathrm{C}-\mathrm{WI}$ (Fig. 7b). This indicated that $\mathrm{NO}$ is more easily oxidized to $\mathrm{NO}_{2}$ on $\mathrm{CrO}_{x} / \mathrm{C}-450$ catalyst with activated oxygen, which probably resulted in the superb $\mathrm{NH}_{3}$-SCR performance of $\mathrm{CrO}_{x} / \mathrm{C}-450$.

In order to confirm whether the formed $\mathrm{NO}_{2}$ participated in $\mathrm{NH}_{3}$-SCR on the $\mathrm{CrO}_{x} / \mathrm{C}$ catalyst, further information about the reaction mechanism was obtained using DRIFTS. In the spectra of the absorption $\mathrm{NO}+\mathrm{O}_{2}$ saturated $\mathrm{CrO}_{x} / \mathrm{C}-450$ sample (Fig. 8a), the bands centered at 1280, 1335, and $1520 \mathrm{~cm}^{-1}$, and a wide band divided into bands at 1730, 1690, and $1660 \mathrm{~cm}^{-1}$ were detected. As reported elsewhere, ${ }^{51}$ these IR bands were attributed to weakly bound $\mathrm{NO}_{2}\left(1730 \mathrm{~cm}^{-1}\right)$, nitrite anion $\left(1335 \mathrm{~cm}^{-1}\right), \nu_{\mathrm{s}}(\mathrm{N}=\mathrm{O})$ and $\nu_{\text {as }}(\mathrm{N}=\mathrm{O})$ of symmetric $\mathrm{N}_{2} \mathrm{O}_{3}(1690$ and $\left.1660 \mathrm{~cm}^{-1}\right)$, bidentate nitrates $\left(1520 \mathrm{~cm}^{-1}\right)$, and monodentate nitrates $\left(1280 \mathrm{~cm}^{-1}\right)$. When the feed gas was switched to $\mathrm{NH}_{3}$, the bands belonging to $\mathrm{NO}_{2}$ and bidentate nitrates gradually disappeared, replacing with the bands of $\mathrm{NH}_{3}$ absorbed on Lewis acid sites (1620 and $1217 \mathrm{~cm}^{-1}$ ), ${ }^{52,53}$ while the bands corresponding to symmetric $\mathrm{N}_{2} \mathrm{O}_{3}$, nitrite anion, and monodentate nitrates were still present. Indeed, it is apparent that
$\mathrm{NO}_{2}$ and bidentate nitrates participated in the surface reaction on $\mathrm{CrO}_{x} / \mathrm{C}-450$ and were consumed by $\mathrm{NH}_{3}$, which is a typical "fast $\mathrm{NH}_{3}$-SCR" pathway. ${ }^{54}$ To determine the role of $\mathrm{NH}_{3}$, coabsorption of $\mathrm{NO}+\mathrm{O}_{2}$ on $\mathrm{CrO}_{x} / \mathrm{C}-450$ after pre-absorption of $\mathrm{NH}_{3}$ was investigated (Fig. 8b). In the spectra of the absorption $\mathrm{NH}_{3}$ saturated $\mathrm{CrO}_{x} / \mathrm{C}-450$ sample, only a weak band at $1620 \mathrm{~cm}^{-1}$ corresponding to $\mathrm{NH}_{3}$ on Lewis acid sites was detected, indicating the low acidity of $\mathrm{CrO}_{x} / \mathrm{C}-450$ as mentioned in $\mathrm{NH}_{3}$-TPD analysis. With the addition of $\mathrm{NO}$ and $\mathrm{O}_{2}$, this band gradually disappeared, accompanied by the appearance of bands belonging to weakly bound $\mathrm{NO}_{2}\left(1732 \mathrm{~cm}^{-1}\right)$, nitrite anion $\left(1333 \mathrm{~cm}^{-1}\right), \nu_{\mathrm{s}}(\mathrm{N}=\mathrm{O})$ and $\nu_{\text {as }}(\mathrm{N}=\mathrm{O})$ of symmetric $\mathrm{N}_{2} \mathrm{O}_{3}$ (1691 and $\left.1657 \mathrm{~cm}^{-1}\right)$, and bidentate nitrates $\left(1515 \mathrm{~cm}^{-1}\right){ }^{51}$
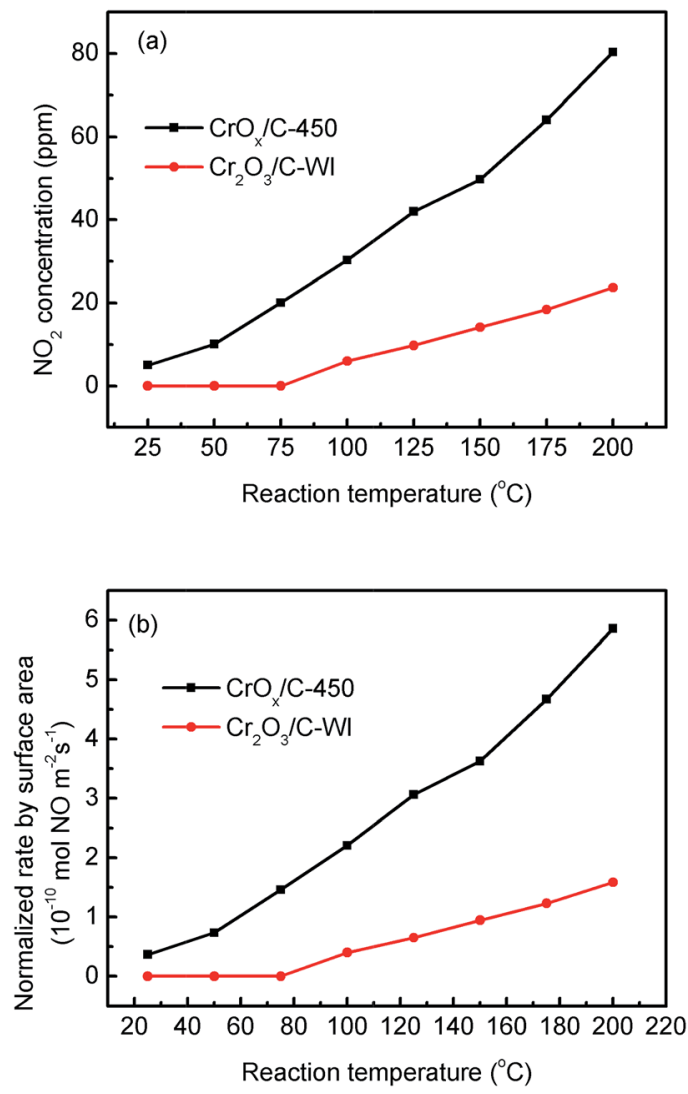

Fig. 7 (a) NO oxidation performances and (b) normalized NO oxidation rate by surface area on $\mathrm{CrO}_{x} / \mathrm{C}-450$ and $\mathrm{C}-\mathrm{Cr}_{2} \mathrm{O}_{3}$ catalysts. 

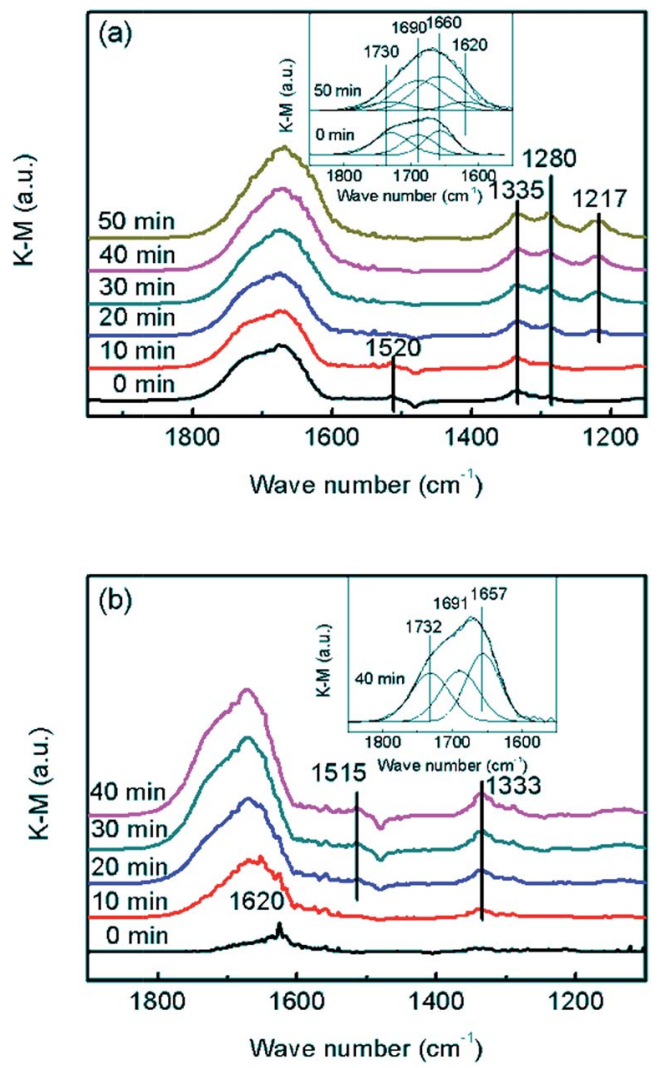

Fig. 8 In situ DRIFT spectra of $\mathrm{CrO}_{x} / \mathrm{C}-450$ : (a) $\mathrm{NH}_{3}$ reacted with preabsorbed $\mathrm{NO}+\mathrm{O}_{2}$, (b) $\mathrm{NO}+\mathrm{O}_{2}$ reacted with pre-absorbed $\mathrm{NH}_{3}$.

This indicated that $\mathrm{NH}_{3}$ on Lewis sites was reacted and consumed. Therefore, the entire $\mathrm{NH}_{3}$-SCR on $\mathrm{CrO}_{x} / \mathrm{C}-450$ followed a $\mathrm{L}-\mathrm{H}$ mechanism, in which $\mathrm{NO}$ was oxidized by the unsaturated oxygen of $\mathrm{CrO}_{x} / \mathrm{C}-450$ catalyst and transformed to $\mathrm{NO}_{2}$. The formed $\mathrm{NO}_{2}$ further absorbed on the surface of $\mathrm{CrO}_{x} /$ C-450 as bidentate nitrates, and reacted with $\mathrm{NH}_{3}$ on Lewis sites, forming $\mathrm{N}_{2}$ and $\mathrm{H}_{2} \mathrm{O}$ at last. Due to the formation of $\mathrm{NO}_{2}$, the reaction proceeded as a "fast $\mathrm{NH}_{3}$-SCR" pathway, causing the decrease in reaction activation energy, thus enhancing the low-temperature activity.

\subsection{Reasons of excellent $\mathrm{SO}_{2}$ tolerance of regeneration ability}

Sulfation process is a transition from metal oxide to metal sulfate. Irrespective of which type of intermediate exists in the sulfation process, the metal-oxygen band must be broken. It is reasonable to deduce that a metal oxide with a strong metaloxygen band is difficult to be sulfated. The $\mathrm{Cr}-\mathrm{O}$ band energy of the eskolaite phase $\mathrm{Cr}_{2} \mathrm{O}_{3}$ was calculated (see the ESI $\dagger$ ). As displayed in Table $55, \uparrow$ the band energy of the $\mathrm{Cr}-\mathrm{O}$ band in the eskolaite phase $\mathrm{Cr}_{2} \mathrm{O}_{3}$ exceeds that of $\mathrm{Mn}-\mathrm{O}$ band in $\mathrm{MnO}_{2}$, indicating that the sulfation process of $\mathrm{Cr}_{2} \mathrm{O}_{3}$ proceeds with more difficulty as compare that of $\mathrm{MnO}_{2}$. This is considered to be the result of the various $\mathrm{NH}_{3}$-SCR performances of $\mathrm{MnO}_{2}$ and $\mathrm{CrO}_{x} / \mathrm{C}-450$ catalyst in the presence of $\mathrm{SO}_{2}$. Moreover, $\mathrm{MnO}_{2}$ and $\mathrm{CrO}_{x} / \mathrm{C}-450$ catalysts deactivated by $\mathrm{SO}_{2}$ were washed with deionized water and the metal-ion contents in the eluate were measured by ICP analysis. As presented in Table $\mathrm{S} 6, \uparrow \mathrm{Mn}^{2+}$ was detected in the eluate of the deactivated $\mathrm{MnO}_{2}$ sample, while no $\mathrm{Cr}^{3+}$ was detected in the eluate of the deactivated $\mathrm{CrO}_{x} / \mathrm{C}-450$ sample. It is evident that the $\mathrm{CrO}_{x} / \mathrm{C}-450$ sample was protected from sulfation.

To further understand the $\mathrm{SO}_{2}$ poisoning and regeneration processes, the XPS spectra of the fresh $\mathrm{CrO}_{x} / \mathrm{C}-450$ catalyst, $\mathrm{SO}_{2}$ poisoned sample, and regenerated sample were studied. As displayed in Fig. 6a and Table 2, the $\mathrm{Cr}$ state and relative content of $\mathrm{Cr}^{6+}$ and $\mathrm{Cr}^{3+}$ of each sample were similar, which indicated that, as it is designed, $\mathrm{CrO}_{x} / \mathrm{C}-450$ catalyst was difficult to be sulfated for the high lattice energy of $\mathrm{Cr}_{2} \mathrm{O}_{3}$. Comparing the $\mathrm{O} 1 \mathrm{~s}$ peak of the fresh $\mathrm{CrO}_{x} / \mathrm{C}-450$ sample and the regenerated sample (Fig. 6b), their peaks of lattice oxygen were similar and both shifted to the high binding energy side than that of bulk $\mathrm{Cr}_{2} \mathrm{O}_{3}$. Since activated lattice oxygen still remained on the surface, the regenerated catalyst exhibited high $\mathrm{NH}_{3}$-SCR activity, similar to the fresh catalyst.

In XPS spectra of the $\mathrm{SO}_{2}$ poisoned sample, the peaks of $\mathrm{S} 2 \mathrm{p}$ and $\mathrm{N} 1 \mathrm{~s}$ were detected. The $\mathrm{S} 2 \mathrm{p}$ peak (Fig. S7a $\dagger$ ) consists of two peaks at $168.5 \mathrm{eV}\left(\mathrm{S} 2 \mathrm{p}_{1 / 2}\right)$ and $169.7 \mathrm{eV}\left(\mathrm{S} 2 \mathrm{p}_{3 / 2}\right)$, which belonged to $\mathrm{SO}_{4}{ }^{2-}$. The $\mathrm{N} 1 \mathrm{~s}$ spectra (Fig. $\mathrm{S} 7 \mathrm{~b} \dagger$ ) can be divided into two peaks at $399.5 \mathrm{eV}$ and $400.5 \mathrm{eV}$, contributed to $\mathrm{NH}_{3}$ and $\mathrm{NH}_{4}{ }^{+}$, respectively. According to the relative atom contents listed in Table S7, $\dagger$ atoms-ratio of $\mathrm{SO}_{4}{ }^{2-}$ and $\mathrm{NH}_{4}{ }^{+}$was nearly $1: 1$ on the surface of the $\mathrm{SO}_{2}$-poisoned sample. This indicated that $\mathrm{NH}_{4} \mathrm{HSO}_{4}$ deposited on the surface of $\mathrm{CrO}_{x} / \mathrm{C}-450$ during the $\mathrm{SO}_{2}$ poisoning process, which causes the deactivation of the catalyst. After heat treatment, the deposited $\mathrm{NH}_{4} \mathrm{HSO}_{4}$ could easily decompose and the $\mathrm{CrO}_{x} / \mathrm{C}-450$ catalyst with exposed activated lattice oxygen regains the superior activity.

\section{Conclusions}

In this study, we successfully designed and synthesized a novel chromium oxide nano-particles catalyst with excellent $\mathrm{NH}_{3}$-SCR activity at $150{ }^{\circ} \mathrm{C}$ and remarkable $\mathrm{SO}_{2}$ regenerative ability. The obtained $\mathrm{CrO}_{x} / \mathrm{C}-450$ catalyst was composed of $\mathrm{CrO}_{x}$ nano-particles covered by amorphous carbon. A carbon species, which was derived from the organic linkers of the MOFs precursor, protected the $\mathrm{CrO}_{x}$ nano-particles from aggregation. $\mathrm{CrO}_{x} / \mathrm{C}$ catalysts primarily have Eskolaite phase $\mathrm{Cr}_{2} \mathrm{O}_{3}$ with average size of $3 \mathrm{~nm}$ and exhibit a large surface area. Due to the small size of $\mathrm{CrO}_{x}$ nano-particles in $\mathrm{CrO}_{x} / \mathrm{C}$ catalysts, the lattice oxygen atoms of $\mathrm{CrO}_{x} / \mathrm{C}$ were activated, so that $\mathrm{NO}$ could be oxidized to $\mathrm{NO}_{2}$ on the catalyst surface. The formed $\mathrm{NO}_{2}$ participated in reaction and made $\mathrm{NH}_{3}-\mathrm{SCR}$ on $\mathrm{CrO}_{x} / \mathrm{C}$ proceed through a "fast $\mathrm{NH}_{3}$-SCR" pathway. The large surface area and activated lattice oxygen of $\mathrm{CrO}_{x} / \mathrm{C}$ catalysts caused the enhanced $\mathrm{NH}_{3}$-SCR activities. Due to the stable lattice of $\mathrm{Cr}_{2} \mathrm{O}_{3}, \mathrm{CrO}_{x} / \mathrm{C}$ catalyst could hardly be sulfated in the $\mathrm{SO}_{2}$ poisoning process. Therefore, the regenerated catalyst still retained prominent activity when $\mathrm{NH}_{4} \mathrm{HSO}_{4}$ deposited on the surface of the catalyst was removed during the regeneration process. 


\section{Conflicts of interest}

There are no conflicts to declare.

\section{Acknowledgements}

The financial supports of National High-tech Research and Development (863) Program of China (2015AA03A401), National Natural Science Foundation of China (No. 21573105), Natural Science Foundation of Jiangsu Province (BK20161392), and Jiangsu Province Science and Technology Support Program (Industrial, BE2014130) are gratefully acknowledged.

\section{References}

1 C. Liu, J. W. Shi, C. Gao and C. M. Niu, Appl. Catal., A, 2016, 522, 54-69.

2 T. H. Vuong, J. Radnik, E. Kondratenko, M. Schneider, U. Armbruster and A. Bruckner, Appl. Catal., B, 2016, 197, 159-167.

3 T. H. Vuong, J. Radnik, M. Schneider, H. Atia, U. Armbruster and A. Bruckner, Catal. Commun., 2016, 84, 171-174.

4 C. J. Tang, H. L. Zhang and L. Dong, Catal. Sci. Technol., 2016, 6, 1248-1264.

5 S. Wu, X. Yao, L. Zhang, Y. Cao, W. Zou, L. Li, K. Ma, C. Tang, F. Gao and L. Dong, Chem. Commun., 2015, 51, 3470-3473.

$6 \mathrm{~K}$. Wijayanti, S. Andonova, A. Kumar, J. Li, K. Kamasamudram, N. W. Currier, A. Yezerets and L. Olsson, Appl. Catal., B, 2015, 166, 568-579.

7 J. H. Lee, Y. J. Kim, T. Ryu, P. S. Kim, C. H. Kim and S. B. Hong, Appl. Catal., B, 2017, 200, 428-438.

8 P. Chen, R. Moos and U. Simon, J. Phys. Chem. C, 2016, 120, 25361-25370.

9 J. Liu, X. Li, Q. Zhao, J. Ke, H. Xiao, X. Lv, S. Liu, M. Tade and S. Wang, Appl. Catal., B, 2017, 200, 297-308.

10 T. Boningari, P. R. Ettireddy, A. Somogyvari, Y. Liu, A. Vorontsov, C. A. McDonald and P. G. Smirniotis, J. Catal., 2015, 325, 145-155.

11 H. Hu, S. X. Cai, H. R. Li, L. Huang, L. Y. Shi and D. S. Zhang, ACS Catal., 2015, 5, 6069-6077.

12 Z. M. Liu, J. Z. Zhu, J. H. Li, L. L. Ma and S. I. Woo, ACS Appl. Mater. Interfaces, 2014, 6, 14500-14508.

13 H. Chang, X. Chen, J. Li, L. Ma, C. Wang, C. Liu, J. W. Schwank and J. Hao, Environ. Sci. Technol., 2013, 47, 5294-5301.

14 J. Li, H. Chang, L. Ma, J. Hao and R. T. Yang, Catal. Today, 2011, 175, 147-156.

15 C. Liu, L. Chen, J. Li, L. Ma, H. Arandiyan, Y. Du, J. Xu and J. Hao, Environ. Sci. Technol., 2012, 46, 6182-6189.

16 L. Zhang, L. L. Li, Y. Cao, X. J. Yao, C. Y. Ge, F. Gao, Y. Deng, C. J. Tang and L. Dong, Appl. Catal., B, 2015, 165, 589-598.

17 D. W. Kwon, K. B. Nam and S. C. Hong, Appl. Catal., B, 2015, 166, 37-44.

18 G. Qi and R. T. Yang, Appl. Catal., B, 2003, 44, 217-225.

19 C. Liu, J.-W. Shi, C. Gao and C. Niu, Appl. Catal., A, 2016, 522, 54-69.
20 M. Colombo, I. Nova, E. Tronconi, V. Schmeißer, B. BandlKonrad and L. Zimmermann, Appl. Catal., B, 2012, 111112, 106-118.

21 S. Roy, M. S. Hegde and G. Madras, Appl. Energy, 2009, 86, 2283-2297.

22 B. Guan, R. Zhan, H. Lin and Z. Huang, Appl. Therm. Eng., 2014, 66, 395-414.

23 S. X. Cai, H. Hu, H. R. Li, L. Y. Shi and D. S. Zhang, Nanoscale, 2016, 8, 3588-3598.

24 E. Rhodes and A. R. Ubbelohde, Proc. R. Soc. A, 1959, 251, 156-171.

25 M. Kang, E. D. Park, J. M. Kim and J. E. Yie, Catal. Today, 2006, 111, 236-241.

26 A. Zhou, D. Yu, L. Yang and Z. Sheng, Appl. Surf. Sci., 2016, 378, 167-173.

27 S. Xiong, X. Xiao, N. Huang, H. Dang, Y. Liao, S. Zou and S. Yang, Environ. Sci. Technol., 2017, 51, 531-539.

28 Q.-l. Chen, R.-t. Guo, Q.-s. Wang, W.-g. Pan, W.-h. Wang, N.-z. Yang, C.-z. Lu and S.-x. Wang, Fuel, 2016, 181, 852-858.

29 H. E. Curry-Hyde, H. Musch and A. Baiker, Appl. Catal., 1990, 65, 211-223.

30 B. L. Duffy, H. E. Curry-Hyde, N. W. Cant and P. F. Nelson, J. Catal., 1994, 149, 11-22.

31 G. Busca, L. Lietti, G. Ramis and F. Berti, Appl. Catal., B, 1998, 18, 1-36.

32 G. Marban, R. Antuna and A. B. Fuertes, Appl. Catal., B, 2003, 41, 323-338.

33 E. Curry-Hyde and A. Baiker, Ind. Eng. Chem. Res., 1990, 29, 1985-1989.

34 S. Alayoglu, A. U. Nilekar, M. Mavrikakis and B. Eichhorn, Nat. Mater., 2008, 7, 333-338.

35 K. Yamamoto, T. Imaoka, W. J. Chun, O. Enoki, H. Katoh, M. Takenaga and A. Sonoi, Nat. Chem., 2009, 1, 397-402.

36 C. T. Campbell and Z. Mao, ACS Catal., 2017, 7, 8460-8466.

37 K. Shen, X. Chen, J. Chen and Y. Li, ACS Catal., 2016, 6, 5887-5903.

38 P. Yin, T. Yao, Y. Wu, L. Zheng, Y. Lin, W. Liu, H. Ju, J. Zhu, X. Hong, Z. Deng, G. Zhou, S. Wei and Y. Li, Angew. Chem., Int. Ed. Engl., 2016, 55, 10800-10805.

39 P. Mahata, D. Sarma, C. Madhu, A. Sundaresen and S. Natarajan, Dalton Trans., 2011, 40, 1952-1960.

40 P. Yin, T. Yao, Y. Wu, L. Zheng, Y. Lin, W. Liu, H. Ju, J. Zhu, X. Hong, Z. Deng, G. Zhou, S. Wei and Y. Li, Angew. Chem., Int. Ed., 2016, 55, 10800-10805.

41 B. You, N. Jiang, M. Sheng, W. S. Drisdell, J. Yano and Y. Sun, ACS Catal., 2015, 5, 7068-7076.

42 J. Yu, F. Guo, Y. Wang, J. Zhu, Y. Liu, F. Su, S. Gao and G. Xu, Appl. Catal., B, 2010, 95, 160-168.

43 S. H. Jhung, J. H. Lee, J. W. Yoon, C. Serre, G. Ferey and J. S. Chang, Adv. Mater., 2007, 19, 121-124.

44 A. Henschel, K. Gedrich, R. Kraehnert and S. Kaskel, Chem. Commun., 2008, 4192-4194.

45 O. Kouvo and Y. Vuorelainen, Am. Mineral., 1958, 43, 10981106.

46 F. Ayari, M. Mhamdi, D. P. Debecker, E. M. Gaigneaux, J. Alvarez-Rodriguez, A. Guerrero-Ruiz, G. Delahay and A. Ghorbel, J. Mol. Catal. A: Chem., 2011, 339, 8-16. 
47 M. A. Henderson and M. H. Engelhard, J. Phys. Chem. B, 2014, 118, 29058-29067.

48 B. Wichterlova, L. Krajcikova, Z. Tvaruzkova and S. Beran, J. Chem. Soc., Faraday Trans. 1, 1984, 80, 2639-2645.

49 D. Shuttleworth, J. Phys. Chem., 1980, 84, 1629-1634.

50 T. Dickinson, A. F. Povey and P. M. A. Sherwood, J. Chem. Soc., Faraday Trans., 1976, 72, 686-705.

51 K. I. Hadjiivanov, Catal. Rev., 2000, 42, 71-144.
52 X. Li, X. Li, J. Li and J. Hao, J. Hazard. Mater., 2016, 318, 615622.

53 Z. Liu, S. Zhang, J. Li and L. Ma, Appl. Catal., B, 2014, 144, 90-95.

54 Y. An, Y. Liu, P. An, J. Dong, B. Xu, Y. Dai, X. Qin, X. Zhang, M.-H. Whangbo and B. Huang, Angew. Chem., Int. Ed. Engl., 2017, 56, 3036-3040. 